\title{
EKSISTENSI DAN KONTRIBUSI PONDOK PESANTREN SABILAL MUHTADIN SEBAGAI PESANTREN TERTUA DI KABUPATEN KOTAWARINGIN TIMUR
}

Saibatul Hamdi

Pascasarjana IAIN Palangka Raya, Kalimantan Tengah, saibatul98.se@gmail.com

Ahmad Muhajir

Pascasarjana IAIN Palangka Raya, Kalimantan Tengah,

\begin{abstract}
Islamic boarding school is the oldest Islamic educational institution that has contributed a lot to the world of education. Sabilal Muhtadin Islamic Boarding School as one of the oldest Islamic boarding schools in East Kotawaringin contributes significantly to the world of Islamic education. This study aims to find out more about; (1) the history of the Sabilal Muhtadin Islamic Boarding School; (2) Tips for the foundation in maintaining the existence of Islamic boarding schools; and (3) the contribution of Islamic boarding schools to the world of Islamic education, especially in Kotawaringin Timur Regency. The method used is a qualitative method by collecting data through interviews, observation and documentation. The results showed that; (1) Sabilal Muhtadin Islamic Boarding School is the oldest Islamic boarding school in Kotawaringin Timur with more than half a century of age and has experienced rapid development over time. (2) Tips for the foundation in maintaining the existence of Islamic boarding schools include increasing levels of education, registering each level at the Ministry of Religion to make it legal and trustworthy, and providing technology to keep up with the times. (3) Islamic boarding school contribution to the world of Islamic education, especially in East Kotawaringin, is to produce quality alumni who play an important role in society. In addition, Sabilal Muhtadin has also been named the most dedicated cottage in Kotawaringin Timur.

Keywords: Contribution, Existence, Islamic boarding school.
\end{abstract}

Abstrak

Pesantren menjadi lembaga pendidikan Islam tertua yang telah banyak memberikan kontribusi terhadap dunia pendidikan. Pondok Pesantren Sabilal Muhtadin sebagai salah satu pondok tertua yang ada di Kotawaringin Timur memberi kontribusi yang cukup besar dalam dunia pendidikan Islam. Penelitian ini bertujuan untuk mengetahui lebih jauh tentang; (1) sejarah berdirinya Pondok Pesantren Sabilal Muhtadin; (2) Kiat-kiat Pihak yayasan dalam mempertahankan eksistensi pondok pesantren; dan (3) kontribusi pondok pesantren terhadap dunia pendidikan Islam khususnya di Kabupaten Kotawaringin Timur. Metode yang digunakan adalah metode kualitatif dengan melakukan pengumpulan data melalui wawancara, observasi, dan dokumentasi. Hasil penelitian menunjukkan bahwa; (1) Pondok Pesantren Sabilal Muhtadin merupakan pondok tertua yang ada di Kotawaringin Timur dengan usia setengah abad lebih dan mengalami perkembangan yang pesat seiring berjalannya waktu. (2) Kiat-kiat pihak yayasan dalam mempertahankan eksistensi pesantren di antaranya dengan memperbanyak jenjang pendidikan, mendaftakan setiap jenjang ke Kementerian Agama agar legal dan dapat dipercaya, serta penyediaan teknologi untuk mengikuti perkembangan zaman. (3) Kontribusi pondok terhadap dunia Pendidikan Islam khususnya di Kotawaringin Timur adalah dengan melahirkan alumni-alumni berkualitas dan berperan penting di masyarakat. Selain itu Sabilal Muhtadin juga dinobatkan sebagai pondok yang paling berdedikasi di Kotawaringin Timur.

Kata Kunci: Eksistensi, Kontribusi, Pesantren

\section{Pendahuluan}

Pendidikan Islam sejatinya mengalami berbagai perkembangan dari zaman ke zaman. Hal ini ditandai dengan berbagai kemajuan yang diraih mulai dari infrastruktur hingga kurikulum yang diajarkan. Sebab pada setiap 
dekadenya, pemerintah bersama para founder lembaga pendidikan saling bersinergi untuk membangun peradaban Pendidikan Islam yang lebih unggul, terdepan, dan terpercaya. Setidaknya, perjalanan sejarah Pendidikan Islam di Indonesia hingga saat sekarang diawali dengan hadirnya pendidikan tradisional. Periode ini ada sejak awal abad ke-20 yang ditandai dengan Pendidikan Islam yang terkonsentrasi kepada pesantren, surau atau masjid dengan berfokus kepada ilmu-ilmu agama yang bersumber dari kitab-kitab klasik (Daulay, 2018: 9).

Salah satu lembaga pendidikan periode awal yang masih eksis hingga sekarang adalah pesantren. Pesantren menjadi lembaga pendidikan Islam yang senantiasa ada pada setiap pelosok tempat. Hal ini menjadi sumber utama sebagai kekuataan penyebaran ajaran Islam itu sendiri. Bahkan pada sebuah studi terdahulu disebut bahwa pesantren merupakan lembaga pendidikan yang memiliki peren sebagai "habitus" sosial masyarakat Islam sebagai mayoritas. Tradisi pesantren yang khas mewariskan nilai-nilai moderat dalam beragama yang terus terjaga hingga kini (Siti Ma'rifah dan Muhammad Mustaqim, 2015: 363-364).

Pesantren memiliki peran yang sangat penting terutama dalam kegiatan pendidikan. Kiprahnya dalam menyelenggarakan pendidikan khususnya pendidikan agama telah teruji sejak lama. Model pendidikan yang khas dan konsisten menjadi daya tarik tersendiri bagi pesantren. Selain itu, pesantren juga merupakan lembaga pendidikan yang berperan besar dalam menciptakan kaderkader da'i maupun pendidik Islam seperti kiayi dan ustadz. Hal ini karena setelah mereka lulus dari pondok pesantren, mereka akan kembali ke kampung halaman dan mengajarkan ilmu-ilmu yang telah diperoleh (Ading Kusdiana, 2014: 2)

Urgensi kehadiran pondok pesantren memberi bukti bahwa eksistensi dan konstribusinya begitu besar terhadap khazanah pendidikan Islam di Indonesia. Hal ini terlihat dari berbagai dimensi pendidikan yang tidak luput dari peran pondok pesantren. Bahkan ketika zaman penjajahan di Indonesia, pesantren hadir sebagai benteng perlawanan terhadap para penjajah. Dengan demikian bahwa amat penting kiranya eksistensi dan konstribusi pondok pesantren terus dipertahankan dalam memajukan pendidikan Islam khususnya di Indonesia.

Kalimantan Tengah sebagai salah satu provinsi yang juga memiliki penduduk muslim terbanyak sudah tak asing lagi dengan keberadaan pesantren. Mengingat di Kalimantan Tengah sendiri banyak terdapat pondok pesantren yang meluluskan santri-santri berkualitas. Berdasarkan data dari Kementrian Agama Provinsi Kalimantan Tengah, hingga 2018 lalu jumlah pondok pesantren yang ada mencapai 78 pesantren yang terdiri dari 13 pesantren Salafiyah dan 65 pesantren Khalafiyah. Pesantren-pesantren tersebut tersebar pada 13 kabupaten dan 1 kota di Kalimantan Tengah (Kemenag Kalteng, 2021).

Jika melihat data secara keseluruhan tentang jumlah pondok pesantren yang ada di Kalimantan Tengah, Kabupaten Kotawaringin Timur menjadi salah satu kabupaten dengan pesantren terbanyak. Jumlah pesantren yang ada di Kotawaringin Timur mencapai 22 pesantren yang terdiri dari 3 pesantren 
Salafiyah dan 19 pesantren Khalafiyah. Di antara pesantren yang ada di Kotawaringin Timur, Sabilal Muhtadin menjadi pesantren tertua yang terletak di Desa Jaya Karet, Kecamatan Mentaya Hilir Selatan.

Penelitian terdahulu tentang eksistensi dan kontribusi pesantren oleh Syamsuri dan Borhan menjelaskan bahwa beberapa kontribusi pesantren di antaranya adalah pesantren sebagai lembaga pengembangan ilmu agama, pesantren sebagai medium dakwah dan tempat perjuangan melahirkan sumber daya manusia, pesantren juga merupakan institusi yang mengabdi bagi masyarakat dengan komitmennya amar ma'ruf nahi munkar dalam berbagai bentuk (Syamsuri \& Joni Tamkin B Borhan, 2016: 220). Penelitian terdahulu menjelaskan lebih detail mengenai eksistensi dan kontribusi pesantren Gontor dalam bidang peningkatan sumber daya manusia, sedangkan penelitian ini mengkaji tentang eksistensi dan kontribusi Pondok Pesantren Sabilal Muhtadin dalam bidang Pendidikan Islam.

Lebih khusus, penelitian ini berupaya untuk menggali informasi mengenai eksistensi dan kontribusi pondok pesantren Sabilal Muhtadin sebagai pondok tertua yang ada di Kotawaringin Timur. Maka artikel ini akan membahas beberapa hal di antaranya; pertama membahas tentang sejarah berdirinya pondok pesantren Sabilal Muhtadin. Kedua, membahas tentang kiat-kiat pihak yayasan dalam mempertahankan eksistensi pondok pesantren hingga sekarang. Ketiga, membahas tentang kontribusi pondok pesantren terhadap pendidikan Islam di wilayah Kotawaringin Timur.

\section{Metode}

Metode yang digunakan dalam penelitian ini adalah metode kualitatif. Teknik pengumpulan data menggunakan wawancara, observasi, dan dokumentasi. Subjek penelitian adalah pengelola yayasan pondok pesantren Sabilal Muhtadin, adapun objek penelitian ini adalah sejarah pesantren, eksistensi dan kontribusinya dalam dunia pendidikan Islam di Kotawaringin Timur. Teknik penentuan informan adalah dengan menggunakan teknik purposive sampling (sampel bertujuan) dengan kriteria bahwa informan tersebut merupakan pengurus resmi yayasan pondok pesantren Sabilal Muhtadin yang aktif dan mengetahui tentang sejarah pondok. Lokasi penelitian adalah di Desa Jaya Karet, Kecamatan Mentaya Hilir Selatan, Kabupatan Kotawaringin Timur. Sementara teknik analisis data menggunakan trianggulasi sumber dan trianggulasi teknik.

\section{Hasil dan Pembahasan}

\section{Sejarah Berdirinya Pondok Pesantren Sabilal Muhtadin}

Pondok pesantren Sabilal Muhtadin merupakan lembaga pendidikan Islam tertua yang ada di Kecamatan Mentaya Hilir Selatan sekaligus di Kotawaringin Timur. Pondok pesantren ini pada mulanya merupakan hasil swadaya masyarakat yang ada di Kayuwara Laut, Desa Jaya Karet Kecamatan Mentaya Hilir Selatan Kabupaten Kotawaringin Timur Provinsi Kalimantan Tengah. Pondok ini didirikan pada tahun 1969 dengan mengusung konsep Madrasah Diniyah dan belum memiliki asrama. Adapun santrinya, selain dari 
dalam daerah, juga ada yang berasal dari luar daerah. Hanya saja mereka dititipkan kepada keluarga atau ada masyarakat yang mau menampungnya selama menuntut ilmu di pondok atau Madrasah Diniyah kala itu (Mieke Nurhayati, 2014:1).

Pada tahun 1972 diteruskan menjadi Madrasah Ibtidaiyah (MI) dan tahun 1977 mulai terdaftar hingga pada tahun ajaran 1979/1980 pertama kalinya mengikuti ujian dan setelah mereka lulus, langsung dikirim ke Pondok Pesantren "Ibnul Amin" Pamangkih Kalimantan Selatan. Sementara santri yang tidak mampu dalam masalah biaya, mereka langsung berhenti (tidak melanjutkan pendidikan).

Tahun 1980, di MI Sabilal Muhtadin didatangkan beberapa ustadz yang dipimpin oleh K.H. Muhammad Yusuf untuk mengasuh sebuah pondok pesantren baru dan juga asramanya. Namun kepemimpinan K.H. Muhammad Yusuf tidak berlangsung lama karena pada tahun 1982 beliau mendapat musibah tenggelam di laut dan tidak diketahui keberadaannya lagi. Selanjutnya, diteruskan oleh K.H. Zainuri HB yang merupakan seorang alumni Madrasah Diniyah Sabilal Muhtadin dan baru pulang belajar dari tanah suci Mekkah. Beliau lah yang kemudian mengasuh dan mengembangkan pondok pesantren hingga menjadi besar.

Perkembangan berikutnya, pada tahun 1987 didirikan Madrasah Tsanawiyah dan Madrasah Salafiyah. Pada tahun 2000 Yayasan Sabilal Muhtadin resmi dinotariskan dengan nomor Akte notaris: 07 Tahun 2000 oleh Notaris Jonie, S.H. dari Sampit. Pada tahun 2002, berdirilah Madrasah Aliyah yang setiap kali penerimaan siswa baru selalu banyak hingga sekarang ini (Mieke Nurhayati, 2014:2).

Kehadiran pesantren ditengah masyarakat amat penting sebagai salah satu kebutuhan pendidikan agama yang semestinya terpenuhi. Hal ini karena pesantren adalah lembaga pendidikan Islam yang secara khusus dan komprehensif menanamkan nilai-nilai keagamaan kepada para santrinya. Sebuah penelitian terdahulu menyebut bahwa pesantren menjadi salah satu wadah untuk penanaman nilai dan etika kepada santri. Hal ini dilakukan ketika pelaksanaan kegiatan rutin maupun insidentil yang memungkinkan interaksi antara Kyai dan santri. Adanya interaksi mengakibatkan penanaman nilai dan etika menjadi lebih mudah sehingga kelak berguna bagi para santri untuk hidup di tengah-tengah masyarakat (Adhe Kusuma Pertiwi, 201: 189).

Ach. Dhofir Zuhry dalam bukunya menjelaskan bahwa seiring dengan perkembangan pesantren menjadi kebutuhan masyarakat mengingat keberadaan madrasah, surau, dan masjid sudah tidak lagi memadai sebagai lembaga pendidikan Islam. Dengan respon positif masyarakat, didirikanlah pesantren-pesantren di seluruh pelosok Indonesia, sehingga jumlah pesantren menjadi banyak (Ach. Dhofir Zuhry, 2018: 159). Begitu pun dengan Pondok Pesantren Sabilal Muhtadin yang kala itu semakin banyak diminati masyarakat sehingga pondok yang dulunya hanya Madrasah Diniyah berkembang pesat menjadi pondok pesantren yang cukup besar hingga sekarang.

Berdirinya Madrasah Diniyah Sabilal Muhtadin juga mampu memberi dorongan kepada masyarakat sekitar untuk memasukkan anaknya ke lembaga 
pendidikan agama Islam agar dapat menjadi penerus para kyai dalam mendakwahkan ajaran Islam di wilayah Kabupaten Kotawaringin Timur. Hal ini sejatinya adalah salah satu fungsi pondok pesantren sebagai tumpuan misi dakwah kalangan internal umat Islam. Sebab sebagai tempat pendidikan agama, keberadaan pesantren menjadi kekuatan penting dalam pendalaman pemahaman agama serta penyebarannya (Ismail Suwardi Wekke dan Mat Busri, 2016: hlm. 5).

\title{
Kiat-Kiat Pihak Yayasan dalam Mempertahankan Eksistensi Pesantren
}

Bertahannya eksistensi Pondok Pesantren Sabilal Muhtadin tidak terlepas dari peran pihak yayasan dalam mengembangkan dan mempertahankan ciri khas pesantren. Berdasarkan wawancara kepada salah satu pengelola yayasan yaitu Ustadzah IQ pada tanggal 11 Agustus 2021 menjelaskan bahwa:

\begin{abstract}
"Ada beberapa faktor yang menyebabkan Pondok Pesantren Sabilal Muhtadin masih tetap bertahan di tengah masyarakat khususnya di Kabupaten Kotawaringin Timur. Pertama, Pondok Pesantren Sabilal Muhtadin merupakan pondok tertua yang ada di Kotawaringin Timur. Hal ini karena pondok pesantren ini telah berdiri selama lebih dari setengah abad."
\end{abstract}

Berdasarkan wawancara tersebut menunjukkan bahwa Pondok Pesantren merupakan pesantren tertua yang ada di Kotawaringin Timur sehingga memuat nilai-nilai sejarah yang begitu banyak. Hal inilah yang kemudian menjadi daya tarik bagi masyarakat untuk terus mengirimkan anakanaknya ke Pondok Pesantren Sabilal Muhtadin dalam rangka mengambil berkah serta kekhasan pondok pesantren yang sarat akan nilai perjuangan.

Fenomena demikian sejatinya merupakan sebuah anggapan yang sejak dulu ada. Sebagian masyarakat menganggap bahwa pondok pesantren yang telah lama berdiri tentu memiliki guru-guru senior yang mempunyai banyak ilmu. Berdasarkan hal itu, para orang tua santri menginginkan anaknya untuk mengambil berkah dari guru-guru tersebut. Dengan demikian bahwa faktor lamanya sebuah pesantren berdiri sejatinya juga menjadi tolak ukur minat masyarakat dalam menyekolahkan anaknya (Abdulloh Hamid, 2017: 88)

Selain sebagai pondok pesantren tertua di Kotawaringin Timur, Sabilal Muhtadin juga merupakan pondok yang memiliki sistem berbeda dari pondokpondok lain khususnya di lingkungan Kecamatan Mentaya Hilir Selatan. Berdasarkan wawancara kepada salah satu pengelola yayasan menyebutkan bahwa:

“Di Kecamatan Mentaya Hilir Selatan sendiri Pondok Pesantren Sabilal Muhtadin bukan satu-satunya pondok pesantren yang mengajarkan ilmu agama, akan tetapi Sabilal Muhtadin memiliki sistem yang berbeda dari yang lainnya bahkan se-Kabupaten Kotawaringin Timur. Di Pondok kami, memiliki pendidikan formal dan pendidikan non formal yang mana keduanya mengajarkan ilmu agama. Untuk pendidikan formal 
sendiri meliputi MI, MTs, dan MA di mana semuanya terdaftar pada bidang pendidikan madrasah Kementerian Agama. Adapun untuk pendidikan non formal yakni Madrasah Salafiyah, PP Sabilal Muhtadin memiliki dua jenjang kesetaraan yaitu Wustho dan Ulya yang terdaftar pada bidang pendidikan Diniyah Pondok Pesantren Kementerian Agama. Semua jenjang tersebut memiliki legalitas yang sama sehingga santri-santri Sabilal Muhtadin dapat melanjutkan ke jenjang yang lebih tinggi. Kelebihan ini yang barangkali tidak dimiliki oleh pesantren lain yang ada di sini. Karena pesantren yang lain hanya memiliki salah satunya saja, yang formal atau non formalnya." (Wawancara kepada Ustadzah RC pada 11 Agustus 2021).

Berdasarkan hasil wawancara tersebut menunjukkan bahwa salah satu upaya dari pihak yayasan untuk terus mempertahankan eksistensi pesantren adalah dengan membuka berbagai jenjang pendidikan. Melihat keadaan ini, Pondok Pesantren Sabilal Muhtadin sejatinya dapat dikategorikan paket komplit sebagai lembaga pendidikan. Kelebihan ini tentu sangat menguntungkan dan begitu mudah menarik minat orang tua untuk menitipkan anaknya di pondok pesantren. Hal ini karena orang tua dapat bebas memilih jenjang yang diinginkan namun tetap dalam lingkungan pondok pesantren.

Selain itu, dengan adanya jenjang pendidikan formal tentu sangat memudahkan santri ketika akan melanjutkan ke jenjang yang lebih tinggi seperti universitas. Sebab mereka telah mendapatkan ijazah yang resmi dari pihak pondok pesantren, ditambah lagi dengan pembekalan ilmu agama yang mumpuni. Bukan hanya pendidikan formal, pendidikan non formal pun juga memiliki ijazah yang resmi yaitu ijazah kesetaraan. Hal ini karena lembaga pendidikan yang ada di Pondok Pesantren Sabilal Muhtadin memiliki legalitas yang sama di Kementerian Agama.

Sejatinya daya tarik pendidikan formal di Pondok Pesantren begitu kuat. Terbukti dari penelitian terdahulu di salah satu pondok pesantren yang menyebutkan bahwa terdapat pengaruh antara variabel pendidikan formal terhadap eksistensi pesantren salafiah di pondok pesantren. Hal ini ditunjukkan dari nilai $T_{\text {hitung }}$ sebesar 12,838 yang lebih besar dari 1,993 (12,838 > 1,993). Hasil penelitian juga menunjukan bahwa nilai determinasi sebesar $69 \%$. Nilai tersebut menggambarkan kondisi bahwa variabel eksistensi pesantren salafiah di pengaruhi oleh pendidikan formal dengan tingkat hubungan sebesar 0.831, yang mendapatkan kategori "Sangat Kuat" Sedangkan sisanya sebesar 30,88\% dipengaruhi oleh variabel lain yang tidak diteliti oleh penulis (Lukman Nulhakim, 2012: 50).

Selain itu, meski pondok pesantren Sabilal Muhtadin menerapkan pendidikan formal, namun tidak meninggalkan ciri khasnya dalam menyelengarakan budaya-budaya pesantren. Sebuah penelitian terdahulu juga menyebutkan bahwa sejatinya pesantren dapat beradaptasi secara arif dengan tantangan zaman dan tuntutan realistis masyarakat disamping mempertahankan ciri khasnya. Alih-alih pesantren tergeser oleh sistem pendidikan formal modern, ia terus bertahan dan justru berposisi sebagai alternatif bagi pendidikan sekolah 
yang lebih cenderung sekuler (Ahmad Syamsu Rizal, 2011: 96.). Hal ini lah yang memicu Pondok Pesantren Sabilal Muhtadin tetap eksis di tengah majunya berbagai pendidikan formal yang lain.

Pondok Pesantren Sabilal Muhtadin tidak hanya mempunyai jenjang pendidikan formal, tetapi juga berusaha untuk mengikuti perkembangan teknologi. Berdasarkan wawancara kepada pihak yayasan menyebutkan bahwa: "PP Sabilal Muhtadin tetap eksis mengajarkan ilmu agama dan salaf serta tidak ketinggalan dengan perkembangan zaman terutama dengan bidang teknologi. Sebagai salah satu contohnya adalah semua jenjang yang melaksanakan ujian nasional disiapkan untuk mengikuti ujian berbasis komputer. Sehingga fasilitas di PP Sabilal Muhtadin disiapkan untuk mengikuti perkembangan teknologi. Begitu pula saat masa pandemi ini, PP Sabilal Muhtadin berusaha untuk memaksimalkan fasilitas yang ada untuk mengikuti anjuran pemerintah dalam melaksanakan pembelajaran jarak jauh secara online. Tetapi yang lebih penting adalah kami selalu melakukan promosi dengan stakeholder terkait untuk menjalin kerja sama dan memperkenalkan PP Sabilal Muhtadin lebih luas lagi." (Wawancara kepada Ustadzah RC pada 11 Agustus 2021).

Berdasarkan hasil wawancara tersebut menunjukkan bahwa Pondok Pesantren Sabilal Muhtadin tidak hanya berfokus kepada pendidikan agama, melainkan juga memperhatikan arus perkembangan zaman terutama perkembangan di era revolusi industri ini. Berdasarkan observasi penulis, di Pondok Pesantren Sabilal Muhtadin memang terdapat ruangan khusus yang berisi komputer untuk keperluan santri dalam mengakses internet maupun untuk ujian. Fasilitas-fasilitas ini tentu memudahkan pihak pondok untuk terus menyelenggarakan pendidikan yang tidak ketinggalan zaman dan dapat bersaing dengan lembaga-lembaga pendidikan di sekitarnya.

Mohammad Takdir dalam bukunya "Modernisasi Kurikulum Pesantren" menjelaskan bahwa pesantren tidak hanya menghadapi tuntutan untuk mempertahankan nilai dan tradisi yang merupakan khazanah intelektual Islam, tetapi juga harus menghadapi amukan globalisasi yang setiap saat dapat meninggalkan sisi tradisionalis pesantren. Bukan hanya itu, globalisasi juga dapat menghancurkan nalar kritis santri yang religius dan Islami. Oleh sebab itu, pengenalan santri terhadap nilai-nilai modernitas salah satunya teknologi begitu penting untuk menunjang kemajuan berpikir dan daya saing di dunia luar. Dengan demikian bahwa pesantren dapat memenuhi kebutuhan umat baik dunia maupun akhirat (Mohammad Takdir, 2018: 15)

Sebuah penelitian terdahulu menyebutkan bahwa dewasa ini pondok pesantren harus meningkatkan mutu pendidikan yang ada sebagai basis bagi pelaksanaan transformasi sosial melalui penyediaan sumber daya manusia yang qualified dan berakhlakul karimah. Oleh sebab itu, pesantren harus semakin bekerja keras untuk memperbaiki segala kekurangannya dan menambah hal-hal yang baru yang menjadi kebutuhan umat sekarang ini. Sebab, model pendidikan pesantren yang mendasarkan diri pada sistem konvensional saat ini belum 
cukup membantu dalam penyediaan sumber daya manusia yang memiliki kompetensi integratif baik dalam penguasaan pengetahuan agama, pengetahuan umum dan kecakapan teknologi (Guntur Cahaya Kesuma, 2017: 77).

Mengacu kepada beberapa paparan di atas, setidaknya terdapat beberapa kiat yang dilakukan oleh pihak yayasan Pondok Pesantren Sabilal Muhtadin tetap eksis hingga saat ini meliputi: pertama, berhasil mempertahankan kekhasan lembaga sebagai pondok pesantren tertua yang ada di Kabupaten Kotawaringin Timur. Kedua, pihak yayasan mengembangkan jenjang pendidikan yang ada di pondok menjadi lebih banyak yaitu pendidikan formal dan non formal yang kesemuanya mempunyai legalitas resmi. Ketiga, selain sebagai pondok yang membekali santrinya dengan ilmu agama, Sabilal Muhtadin juga memperhatikan era perkembangan zaman dengan memajukan penggunakan teknologi di pondok pesantren.

Pondok Pesantren Sabilal Muhtadin terbukti dapat mempertahankan eksistensinya hingga kini. Jika dianalisis menggunakan teori eksistensi yang dikemukan oleh Kierkegaard ada beberapa hal yang dapat dikaji sebagai berikut.

Eksistensialisme secara etimologi berasal dari bahasa Latin yaitu existere yang berarti muncul, ada, timbul, memilih keberadaan aktual. Sementara eksistensialisme merupakan gerakan filsafat yang menentang esensialisme, pusat perhatiannya adalah situasi manusia (Lorens Bagus, 2005: 185). Menurut Kierkegaard, suatu keputusan yang berani diambil oleh manusia untuk menentukan hidupnya, dan menerima konsekuensi yang telah diambil. Jika manusia takut untuk melakukannya, maka manusia tersebut tidak bereksistensi dengan sebenarnya. Dalam teorinya, Kierkegaard membagi tahapan eksistensi menjadi tiga yaitu tahap estetis (the aesthetic stage), etis (the ethical stage), dan religious (the religious stage) (F. Budi Hardiman, 2007: 251).

\section{Pertama, Tahap Estetis (the aesthetic stage)}

Menurut Kierkegaard, pada tahap ini sejatinya manusia tidak memiliki ketenangan. Hal ini karena ketika manusia telah memperoleh sesuatu yang diinginkan, maka ia akan berusaha kembali untuk memenuhi keinginannya yang lain. Hal ini tentu terkait dengan kebutuhan yang terus melekat pada naluri manusia itu sendiri. Ringkasnya adalah manusia tidak pernah puas dengan apa yang didapatnya. Bahkan manusia tidak terkadang berada pada titik nol ketika tidak dapat memenuhi harapannya. Sehingga pada tahap ini muncul beberapa pilihan seperti kepuasan atau frustasi, nikmat atau sakit, senang atau susah, ekstasi atau putus asa (Hidya Tjaya, 2004: 89)

Terkait hal ini, Pondok pesantren melakukan inovasi-inovasi untuk tetap mempertahankan eksistensinya. Sebagai contoh pondok pesantren membuka jenjang pendidikan baru yang menjadi kebutuhan masyarakat. Hal ini menunjukkan bahwa pihak pesantren tidak puas dengan pencapaian yang ada kemudian melakukan terobosan-terobosan baru agar pondok tetap eksis di tengah berbagai tuntutan yang ada.

\section{Kedua, Tahap Etis (ethical stage)}

Tahap etis ini merupakan tahap yang lebih tinggi dari tahap sebelumnya. Pada tahap ini manusia memperhatikan aturan-aturan universal yang berlaku. Bahkan manusia menganggap bahwa aturan atau norma merupakan suatu hal 
yang dibutuhkan dalam kehidupannya. Etis berarti benar-benar menginginkan adanya aturan karena aturan dapat membimbing dan mengarahkannya. Terkait dengan perkembangan pesantren dan madrasah, sejatinya para pejuang dan pendirinya berusaha untuk seirama dengan aturan dan norma yang berlaku di masyarakat agar mereka dapat diterima. Sebab aturan yang berlaku menjadi nilai-nilai yang terus digemakan dan pantang untuk diacuhkan.

Terkait tahap ini, Pondok Pesantren Sabilal Muhtadin selalu mengedepankan aturan-aturan yang berlaku agar jenjang pendidikan di pesantren ini tidak dinilai ketinggalan dan tidak legal. Hal ini dibuktikan dari jenjang pendidikan yang telah terdaftar di Kementerian Agama baik jenjang pendidikan formal maupun non formal. Selain itu, pihak pesantren selalu mengikuti perkembangan yang berlaku misalnya pelaksanaan ujian berbasis komputer, penyediaan pendidikan kesetaraan di Madrasah Salafiyah dan berbagai

\section{Ketiga, Tahap Religious (the religious stage)}

Tahap ini merupakan tahapan tertinggi dalam teori eksistensi Kierkegaard. Pada tahap ini keputusasaan dianggap sebagai cara cepat untuk menuju kepercayaan. Keputusasaan merupakan tahap menuju permulaan yang sesungguhnya, dan bukan menjadi final dalam kehidupan. Sehingga keputusasaan dijadikan sebagai tahap awal menuju eksistensi religius sebenarnya. Pada akhirnya keputusasaan yang diringi dengan kesadaran untuk menyerahkan diri kepada Tuhan mengingat ada realitas Tuhan sebagai pedoman. Sehingga dalam menghadapi problematika yang terjadi tidak akan goyah sebab berpegang pada tali yang kuat yaitu keyakinan. bahwa:

Berdasarkan hasil wawancara kepada pihak yayasan menyebutkan

"Salah satu nilai khas yang masih dipertahankan ada pada Madrasah Salafiyah sebagaimana yang telah dicontohkan oleh ayah pengasuh dulu yaitu belajar dengan keikhlasan, Madrasah Salafiyah menjadi salah satu jenjang yang berusaha untuk menciptakan kader-kader ulama yang mumpuni dalam ilmu agama serta berakhlakul karimah di masa depan. Walau pun saat ini kita dihadapkan pada berbagai pengaruh dunia global."(wawancara kepada Ustadzah IQ pada 11 Agustus 2021)

Hal ini menunjukkan bahwa meski dihadapkan pada berbagai tantangan global dewasa ini, pihak pesantren senantiasa memprioritaskan pendidikannya kepada tujuan yang hakiki yaitu belajar dengan keikhlasan. Pihak yayasan meyakini bahwa jika pondok masih mempertahankan nilai-nilai ini, maka eksistensinya tak akan pernah luntur. Sebab sasaran utama hanya untuk merealisasikan tujuan pendidikan agama sesungguhnya yaitu menicptakan generasi-generasi yang cerdas dan berakhlakul karimah.

\section{Kontribusi Pondok Pesantren Terhadap Pendidikan Islam Di Wilayah Kotawaringin Timur}

Sebagai pondok pesantren tertua yang ada di Kabupaten Kotawaringin Timur, Sabilal Muhtadin tentu memiliki kontribusi besar terhadap pendidikan Islam. Berdasarkan hasil wawancara kepada pihak yayasan menyebutkan 
bahwa:

"Sebagai pondok pesantren yang tertua di Kotawaringin Timur, konstribusinya menciptakan lebih banyak generasi yang memiliki ketakwaan, akhlak yang mulia, kecerdasan, mempunyai daya saing di bidang sains dan teknologi sehingga bisa bertahan di era globalisasi namun tetap berlandaskan Alquran dan Sunnah, sehingga generasigenerasi seperti ini mampu berdaya di masyarakat. Banyak alumni pondok kami yang menjadi ulama, guru, dan aktif pada berbagai kegiatan-kegiatan penting di masyarakat."

Berdasarkan hasil wawancara di atas menunjukkan bahwa sejatinya kontribusi Pondok Pesantren Sabilal Muhtadin di Kotawaringin Timur begitu besar, mengingat pada awal berdirinya pesantren ini menjadi pusat pendidikan agama di masyarakat khususnya di Kecamatan Mentaya Hilir Selatan. Sehingga peranya begitu besar, terbukti dari tersebarnya para alumni-alumni pondok yang kini telah sukses dengan tetap memegang teguh ajaran-ajaran agama yang dulu didapatkan ketika di pesantren. Alumni-alumni ini yang semakin membuat pondok pesantren menjadi terkenal dengan memperlihatkan kontribusinya pada bidang pendidikan Islam.

Sebuah penelitian terdahulu menyebut bahwa pesantren telah memberikan kontribusi yang cukup besar terhadap sistem pendidikan nasional untuk memanusiakan manusia sekaligus memuliakan manusia agar kembali ke kodratnya yang sebenarnya sebagai makhluk ciptaan Allah swt yang paling sempurna dan paling mulia (Suddin Bani, 2015: 273). Hal ini senada dengan kontribusi Pondok Sabilal Muhtadin yang memiliki andil besar dalam memanusiakan manusia dengan membekali berbagai keahlin yang sesuai perkembangan zaman namun tetap mempertahankan nilai-nilai agama yang sejatinya selalu terpatri di dalam jiwa. Selain itu, kontribusi ini menjadi bagian penting untuk menjawab dan menepis anggapan masyarakat mengenai pesantren yang dianggap tertinggal.

Selain itu, Pondok Pesantren Sabilal Muhtadin juga menjadi salah satu pesantren yang berdedikasi di Kotawaringin Timur. Wawancara kepada pihak yayasan menyebutkan bahwa:

“Pondok pesantren kami pernah mendapatkan terbaik I sebagai pondok yang berdedikasi yang ada di Kotawaringin Timur. Hal ini menjadi suatu kebanggaan dan tuntutan juga bagi kami untuk terus mengembangkan pondok menjadi lebih baik lagi. Kami juga berharap dengan adanya kontribusi ini semakin menambah minat dan kepercayaan masyarakat untuk menitipkan anak-anaknya di pondok kami." (Wawancara kepada Ustadzah RC pada 11 Agustus 2021).

Berdasarkan hasil wawancara tersebut terlihat bahwa kontribusi Pondok Pesantren Sabilal Muhtadin benar-benar terbukti dan mendapatkan pengakuan dari pemerintah daerah sebagai lembaga pendidikan yang berjasa. Tidak heran jika penghargaan tersebut diberikan atas keberadaannya yang telah cukup lama dan menghasilkan alumni-alumni berkualitas di Kotawaringin Timur. Predikat 
yang diterima ini tentu semakin menuntut pihak yayasan untuk terus memperbaiki kualitas pendidikan di pondok serta pelayanan kepada masyarakat.

Pesantren sejatinya harus memberikan kontribusi terhadap masyarakat terutama kepada santrinya. Kontribusi tersebut berupa pembekalan keahlian kepada santri sebagai bekal dalam menghadapi tantangan zaman terutama menghadapi Masyarakat Ekonomi Asean kedepan. Artinya adalah kontribusi pesantren tidak hanya sebatas pendidikan agama, melainkan dapat melahirkan skill-skill baru untuk santri agar dapat menembus tantangan dunia nantinya (Ishomuddin dkk, 2016: 292). Maka terkait hal ini, Pondok Pesantren Sabilal Muhtadin kiranya dapat memberikan kontribusi yang lebih dengan mengembangkan pendidikan yang ada untuk membekali santri dengan skill mumpuni. Langkah ini juga merupakan tuntutan dari predikat yang telah didapatkan sebagai pesantren yang berdedikasi di Kotawaringin Timur.

Sebuah penelitian terdahulu menyebutkan bahwa pesantren tetap menjadi primadona masyarakat dalam membendung derasnya arus globalisasi dan budaya budaya barat yang menggurita. Sehingga prospek pesantren sebagai lembaga pendidikan Islam kedepan masih tetap cerah dan dibutuhkan (Hamruni \& Ricky Satria W., 2016: 208). Begitu pun dengan Pondok Pesantren Sabilal Muhtadin, dalam menangkal pengaruh globalisasi saat ini masyarakat mempercayakan salah satu lembaga pendidikan Islam ini sebagai tempat untuk anak-anak mereka menimba ilmu dan meredam dampak negatif globalisasi.

\section{Kesimpulan}

Pondok Pesantren Sabilal Muhtadin merupakan pondok pesantren tertua yang ada di Kabupaten Kotawaringin Timur dengan usia yang lebih dari setengah abad. Pesantren ini dibina oleh seorang Kiai yang bernama K.H. Zainuri HB yang kemudian setelah beliau meninggal diteruskan oleh pihak yayasan. Ada beberapa kita-kiat yang dilakukan oleh pihak yayasan guna mempertahankan eksistensi pondok pesantren seperti memperluas dan memperbanyak jenjang pendidikan yang ada di pondok. Selain itu, jenjang pendidikan yang ada mendapatkan pengakuan yang legal dari Kementerian Agama sehingga ketika santri telah lulus dapat melanjutkan ke jenjang yang lebih tinggi. Pihak pondok juga terus mengikuti perkembangan dengan memperhatikan penggunaan teknologi pada berbagai bidang. Adapun kontribusi pondok pesantren terhadap pendidikan Islam di Kotim begitu besar terbukti dari tersebarnya para alumni yang sangat berperan di masyarakat hingga mengantarkan Sabilal Muhtadin sebagai salah satu pondok yang berdedikasi. 


\section{Daftar Pustaka}

Bagus, Lorens. Kamus Filsafat. Jakarta: Gramedia Pustaka Utama, 2005.

Bani, Suddin. "Kontribusi Pesantren dalam Sistem Pendidikan Nasional". Jurnal Auladuna, Vol. 2, No. 2, 2015: 264-273.

Daulay, Haidar Putra. Sejarah Pertumbuhan dan Pembaruan Pendidikan Islam. Jakarta: Kencana, 2018.

Hamid, Abdulloh. Pendidikan Karakter Berbasis Pesantren. Surabaya: Imtiyaz, 2017.

Hamruni \& Ricky Satria W.. "Eksistensi Pesantren dan Kontribusinya dalam Pendidikan Karakter". Jurnal Pendidikan Agama Islam, Vol. XIII, No. 2, 2016: 197-210.

Hardiman, F. Budi. Filsafat Modern Dari Machiavelli Sampai Nietzsche. Jakarta: Gramedia, 2007.

Ishomuddin dkk. "Pembangunan Sosial dalam Menghadapi Masyarakat Ekonomi Asean”. Prosiding Seminar Nasional. Jawa Timur: Duta Media Publishing, 2016.

Kemenag

Kalteng.

https:/ / kalteng.kemenag.go.id/file/file/GONDO/5121573167515.pdf,. Akses pada 30 November 2020.

Kesuma, Guntur Cahaya. "Refleksi Model Pendidikan Pesantren dan Tantangannya Masa Kini". Tadris: Jurnal Keguruan dan Ilmu Tarbiyah, Vol. 02, No. 01, 2017: 67-79.

Kusdiana, Ading. Sejarah Pesantren. Jakarta: Humaniora, 2014.

Ma'rifah, Siti \& Muhammad Mustaqim. "Pesantren Sebagai Habitus Peradaban Islam Indonesia”. Jurnal Penelitian, Vol. 9, No. 2, 2015: 347-364.

Nulhakim, Lukman. "Pengaruh Pendidikan Formal Terhadap Eksistensi Pesantren Salafiah di Pesantren An-Nur Kecamatan Cilawu Kabupaten Garut". Jurnal Pendidikan Universitas Garut, Vol. 06, No.1, 2012: 32-51.

Nurhayati, Mieke. Biografi Seorang Guru Madrasah: Kisah Perjalanan Hidup H.M.Arfan. Yogyakarta: Deepublish, 2014.

Pertiwi, Adhe Kusuma dkk. "Analisis Interaksi Simbolik Kyai dan Santri dalam Perspektif Kepemimpinan Berbasis Nilai dan Etika". Jurnal Manajemen dan Supervisi Pendidikan, Vol. 2, No. 3, 2018: 185-191. 
Rizal, Ahmad Syamsu. “Transformasi Corak Edukasi dalam Sistem Pendidikan Pesantren, dari Pola Tradisi ke Pola Modern". Jurnal Pendidikan Agama Islam Ta'lim, Vol. 9, No. 2, 2011: 95-112.

Syamsuri \& Joni Tamkin B Borhan. “Eksistensi dan Kontribusi Pondok Modern Darussalam Gontor dalam Pembangunan Sumber Daya Manusia". Jurnal At-Ta'dib, Vol II, No. 2, 2016: 202-222.

Takdir, Mohammad. Modernisasi Kurikulum Pesantren. Yogyakarta: Diva Press, 2018.

Tjaya, Hidya. Kierkegraard dan Pergulatan Menjadi Diri Sendiri. Jakarta: Gramedia, 2004.

Wekke, Ismail Suwardi \& Mat Busri. Kepemimpinan Transformatif Pendidikan Islam: Gontor, Kemodernan, dan Pembelajaran Bahasa. Yogyakarta: Budi Utama, 2016.

Zuhry, Ach. Dhofir. Peradaban Sarung. Jakarta: Elex Media Komputindo, 2018. 